\title{
5 Informal transport worker organizations and social protection provision in Kenya
}

Anne W. Kamau

\section{Introduction}

Kenya's transport sector is dominated by road transport which accounts for over 80 percent of total passenger traffic and 76 percent of freight. The informal road transport modes include public service modes such as the paratransits commonly known as 'matatu' and the motorcyclists commonly known as bodaboda. The two are common modes of passenger transport in Kenya (Behrens et al., 2017; Mutongi, 2017). Paratransits or matatus are also referred to as public service vehicles (PSVs) and are often used interchangeably, even though the term PSV includes other modes like passenger transport motorcycles. This chapter focuses on paratransit and motorcycle sub-sectors workers in the urban areas of Nairobi and Kisumu cities in Kenya. The two modes employ a large pool of informal workers who directly and indirectly depend on the sector. The matatus sub-sector direct beneficiaries include the vehicle owners, drivers, conductors, fleet managers, stage managers, callers, and loaders, while the indirect workers include mechanics, painters, graffiti artists, and cleaners (Wright, 2018). For the motorcycles sub-sector, the key actors are the riders and owners. Despite many players in the transport sector, there is no reliable data on number of workers. Spooner and Whelligan (2017) estimated that, in 2017, over 100,000 PSVs had been registered, while Opondo and Kiprop (2018) estimated that about $1,393,390$ motorcycles were registered in 2018.

This chapter focuses on informal transport workers in the paratransits and motorcycles sub-sectors in Kenya, their social protection coverage, and the role of associations. The chapter is based on data obtained through research undertaken in Nairobi and Kisumu between June and December 2018. The collaborative study used quantitative and qualitative methods in data collection that included a survey of 200 informal public transport workers, focus group discussions with workers and vehicle owners, and key informant interviews with representatives of government organizations, workers' associations, and unions. The chapter starts with a reflection on governance of the sector, followed by a discussion on formality and informality. It then reflects on workers' associations and an analysis of the study findings on workers characteristics and associations' membership. The chapter uses the power resources analytical framework to discuss the role of 
associations in promoting workers access to social protection and concludes with reflections on the two sub-sectors.

\section{Transport sector governance}

The public transport sector in Kenya is privately organized and governed through a top-down structure. The sector is regulated through complex multi-layered and multi-agency systems that have formal and informal regulations and controls. Different agencies regulate different aspects of the sector, albeit sometimes with overlapping and conflicting roles (World Bank, 2019). The most prominent agency is the National Transport and Safety Authority (NTSA). Its mandate is to develop and implement traffic regulations, registration, and issuance of motor vehicle licenses, inspection and certification, and advising government on national road transport sector policy issues. NTSA also requires PSVs to be installed with digital speed governors, seat belts to enhance passenger safety, fleet monitoring system for vehicles travelling at night, and to undergo annual inspection (ROK, 2012a, 2012b). Enforcement of these regulations is undertaken jointly by the NTSA, the National Police Service (NPS), and the motor-vehicles inspection units. Other government agencies that play crucial roles in the sector operations include the State Department for Co-operatives of the Ministry of Industry, Trade and Co-operative, and the Criminal Investigation Department (CID).

An example of multi-agency sector regulation is the implementation of the NTSA Legal Notice 161 of 2012 that requires all PSVs to join transport Savings and Credit Co-operative Societies (SACCOs) or transport management companies (TMCs). The SACCOs and TMCs are registered by the State Department for Co-operatives and are expected to manage vehicles registered under them and clear workers for licensing by NTSA and issuance of Certificate of Good Conduct by the CID (NTSA, 2014). This chapter uses the term SACCOs to refer to both the SACCOs and TCMs as there is no clear conceptual difference between the two terms. Initially, most operators had registered companies which were later transformed into SACCOs in order to comply with the NTSA requirements. There is no reliable data on the number of transport SACCOs and companies registered in Kenya. Estimates suggest that Nairobi alone has about 692 registered SACCOs, but only about 272 are registered with the NTSA to operate (Omulo, 2020; Mwanza, 2021), suggesting that about 420 SACCOs that are in government records as registered are not licensed by the NTSA to operate.

\section{Formality versus informality in the transport sector}

The question of formality and informality generates varying views. The 'formal' perspective asserts that the sector has formal structures and regulations that govern its operations. The formalization process, according to this view, begins when operators and workers engage with the formal systems involved in inspection, licensing and certification of vehicles, and licensing of operating routes and workers. An example is the formal registration process that requires matatu 
operators to join SACCOs to be licensed by NTSA and the workers to get clearance from the CID so as to be licensed to work in the sector. Informality starts at the level of operations which are mainly informal, according to this view. As argued, operators enter the sector through formal systems but become informal once they begin to work. The view that considers the sector as 'informal' bases its arguments on the precarious working conditions that characterize the sector such as job insecurity, lack of formal contracts, irregular and unreliable incomes based on targets, lack of leave days or official retirement, limited or no access to credit, and generally, weak representation. This is despite existence of legislation that would enhance formalization of the sector, for instance, the requirement to provide formal work contracts to drivers and conductors in the matatu subsector. There is thus a contradiction between the existing legal frameworks and the practice. Hence, the challenge in Kenya is not the absence of laws to protect workers but lack of enforcement and supporting systems, and this makes the sector prone to remain being informal.

\section{Services offered by transport associations}

Kenya's transport sector is largely association-based, and for the matatu's sub-sector, it is mandatory for PSV operators to join transport SACCOs. This is, however, not required of the motorcycle (bodaboda) operators. Nonetheless, they also belong to sub-sector-based associations. The informal transport workers' SACCOs and associations can play a role in ensuring workers' access to formal social protection. However, evidence suggests that most of these workers, like other informal sector workers, lack access to formal social protection, for instance, health insurance. Even when enrolled in social security schemes, they also depend on informal networks to meet their welfare needs. This chapter explores the role of transport associations in enhancing workers access to formal and informal social protection in line with the preventive, promotive, and transformative framework elaborated by Devereux and Sabates-Wheeler (2004).

\section{Preventive}

Preventive measures seek to avert deprivation or destitution, with a focus on risk mitigation and diversification, for instance, by providing or promoting access to social insurance. The transport sector is a high-risk sector that is prone to accidents, and workers are exposed to continuous risks. They face health and social challenges that include exposure to noise and air pollution, eye problems, fatigue, and exhaustion due to working for long hours and sometimes working in a hostile environment. To avert possible occupational hazards and the possible poor health, it is important for the sector's actors to invest in preventive measures. This investment could include enrolment of workers in social insurance schemes and improvement of the working environment. Examples of preventive measures include the NTSA Act of 2014 which requires SACCOs to employ workers on formal work contracts, provide them with leave days, and make 
statutory contributions to health and pension schemes. Employers are also expected to ensure health and safety of the workplace and comply with the Work Injuries Benefits Act (WIBA) No. 13 of 2011 (ILO, 2020). Also, the Kenya subsidiary legislation of 2020 requires drivers to undergo medical examination before being issued with driving licences to assess their fitness (ROK, 2020).

The National Health Insurance Fund (NHIF) and the National Social Security Fund (NSSF) are examples of social security programmes that transport workers can enrol in. Survey findings in this study showed that 47 percent of workers had formal insurance (slightly higher for health insurance coverage), with the vast majority referring to the NHIF, followed by the NSSF and other types including the one-year universal health pilot programme rolled out in 2018. Discussions with key informants revealed that some workers enrol in insurance programmes, especially the NHIF, voluntarily without influence from the SACCOs. In some cases, though not common, SACCOs like the Kangemi Matatu Owners (KMO) in Nairobi, Kihomi Sacco in Kisumu and Kisumu Ahero Mowouk Transport Company encourage workers to enrol in health insurance programmes. Further, some SACCOs make daily deductions from the workers' wages and remit the pooled savings to the schemes on monthly basis on behalf of workers. In this case, the employer enables the workers to pay for social security coverage but do not pay for the workers' coverage. Nonetheless, most workers are reluctant to join employer-linked social security programmes due to fear that their job mobility might be restricted. Low awareness about social protection schemes and superstition that taking health insurance is a bad omen leaves many workers without coverage. Results also indicate that most workers belong to associations that cater for their welfare needs like bereavement, sickness, and school fees support. Such support is often limited and may not cover full costs, for instance, in case of hospitalization as would be the case with NHIF.

\section{Promotive}

Promotive measurers are aimed at enhancing real incomes and the productive capacity of workers. In this study, such measures include training and capacitybuilding of workers, and those that enhance workers' financial investments and savings. Examples of promotive measures were evident in the study, for instance, where SACCOs facilitated workers training on financial literacy, road safety, and investment in social protection. Some support workers' access to credit from financial institutions like the Kenya Union of Savings and Credit Cooperatives (KUSCCO), and banks like Equity and Family banks. There are also those that promote workers' investment through savings, share-holding, or contributions. The money is used to purchase SACCO or company vehicles, individual, or association motorcycles or to access loans. Most associations and some SACCOs pay annual dividends to members from these investments. In most cases, even with informal associations, the annual sharing of dividends is common, and members are free to use their money in the way they prefer, like paying school fees and meeting festivities cost. However, hardly is the money 
used to pay for social security. Hence, some key informants emphasized the need to sensitize workers about investing in their own social security. As noted by Kamau et al. (2019), informal sector workers have different peak seasons that social security schemes could target to expand coverage. In the case of the transport sector, the peak season is in December, and agencies like the NHIF and NSSF could engage workers during this period to encourage them to pay for social security.

\section{Transformative measures}

A transformative social protection approach addresses issues of social equity and inclusion by focusing on policies and legislations as well as taking measures that include collective action for workers' rights. Results showed weaknesses in the transformative role of associations, especially in enabling workers' access to social protection. In the survey, only 9 percent of association members reported representation and voice as a key benefit, and this was mainly about engagement with authorities to address challenges facing workers like harassment by authorities, petitioning the government to rescind decisions considered a threat to the sector such as removal of 14-seater matatus from the sector, or lobbying the government to undertake interventions to improve the sector operators such as improving roads. Some SACCOs also intervene to discourage the rent-seeking behaviour which involved payment of bribes to police and cartels, as noted by 61.4 percent of surveyed workers. Some SACCOs instruct workers not to pay bribes and instead to contact them if they have problems with authorities. On the extreme side like in Kisumu, some SACCOs encourage workers not to wear uniforms to avoid being easily identified by authorities. Despite this, the workers rarely contact their associations on policy, regulatory, or work-related issues affecting them. From the survey, 23.5 percent of workers had contacted their SACCOs to get welfare support, 6.5 percent for associations to negotiate with the authorities, and 4.5 percent to get help on work-related issues like better terms of employment and salary payment, increase, or promotion.

There is no common bargaining agreement on workers' rights, and labour issues are hardly pursued. Formal work contracts are hardly provided to workers despite being in the sector for long. In the survey, only 1.5 percent of workers had written contracts, 18.5 percent had verbal contracts, 23 percent day contracts, and the rest (23 percent) had no contracts at all. Hence, workers have no legal protection and can easily lose jobs if they fail to meet targets or disagree with their employers. Nonetheless, some SACCOs such as Kihomi in Kisumu and Kisumu Ahero Mowouk Transport Company (KAMTCO) employ workers on formal work contracts if they work for the vehicles that are franchised to the SACCOs. As observed:

There is no employee protection from the employer in case of a dispute. The employee has no job security since there is no contract. They also do not enjoy benefits such as leave allowance. The income in this sector is unreliable. 
Among the boda-boda group the sector is informal and they depend on chamas in case of illness or accidents. There are those who have NHIF cards through individual arrangements.

(FGD, Nairobi)

Workers' representation is weak, and most SACCOs and vehicle owners are reluctant to support workers to join unions. The common trend among the workers is to change or quit their jobs if they are dissatisfied as opposed to contacting their employers to voice their concerns. This results in high workers turn-over and the consequent low social security coverage. The exit option is a weaker strategy as it does not help to create stable work environments. McClean, Burris, and Detert (2013) noted that "voice and exit are directly inversely related" and that often employees have two distinct choices which entail (i) choosing voice or silence and (ii) choosing to stay or exit their organization. This, according to McClean et al., implies that "employees may sometimes speak up and remain in their organization irrespective of how much or how quickly things change", or they "may speak up and subsequently exit the organization because of what happens (or fails to) in response to voice". The fact that workers can be dispensed at any time by their employers makes them opt for the exit option. This resonates with McClean et al.'s view that voice does not automatically make things better or worse for those who speak up or anyone else, and as noted by FGD participants in Kisumu,

Jobs in the sector are insecure and a driver considers himself as working by having the key. It is common for the owner of the vehicle to inform the driver that he is using it for other things like travel, only for the driver to find it on the road with another driver.

(FGD, Kisumu)

\section{Transport workers' characteristics}

This study covered matatus workers - drivers and conductors - who comprised 58 percent of the survey sample and motorcycle operators (bodaboda) who made up 42 percent. Transport workers are generally young with a mean age of 36 years and most are married ( 86 percent). Around 29 percent were born in the city where they work, though this is much lower for Nairobi at 13 percent, indicating the high extent of urban migration which is most likely work related. As seen in Table 5.1, membership in associations is 67 percent and is substantially higher in Kisumu compared with Nairobi. By contrast, formal social insurance enrolment, which is 47 percent overall, is higher in Nairobi compared with Kisumu, and for health insurance coverage, the difference between the two cities is even larger, with Nairobi having a coverage rate of 59 percent.

The vast majority of transport workers are men, though with 7 percent women in Kisumu. In the survey, all drivers and motorcycle riders were men. The absence of women is linked to the nature of the transport sector work which 
Table 5.1 Key worker characteristics

\begin{tabular}{lrrrrrrr}
\hline & All & \multicolumn{4}{c}{ Nairobi } & \multicolumn{3}{c}{ Kisumu } \\
\cline { 2 - 8 } & Mean & SD & Mean & SD & Mean & SD \\
\hline Association membership* & 0.67 & 0.47 & 0.60 & 0.49 & 0.78 & 0.42 \\
Social insurance enrolment & 0.47 & 0.50 & 0.52 & 0.50 & 0.42 & 0.50 \\
Health insurance coverage & 0.50 & 0.50 & 0.59 & 0.49 & 0.37 & 0.49 \\
Male & 0.97 & 0.17 & 1.00 & 0.00 & 0.93 & 0.26 \\
Age & 36.16 & 8.89 & 35.75 & 9.52 & 36.73 & 7.97 \\
Married & 0.86 & 0.34 & 0.84 & 0.37 & 0.90 & 0.30 \\
Born in local city/town & 0.29 & 0.45 & 0.13 & 0.34 & 0.51 & 0.50 \\
Mean wage in USD & 10.95 & 7.09 & 12.42 & 7.98 & 8.93 & 5.00 \\
Assets ownership (house, land) & 0.28 & 0.45 & 0.27 & 0.44 & 0.29 & 0.45 \\
Primary education incomplete & 0.11 & 0.31 & 0.07 & 0.25 & 0.15 & 0.36 \\
Primary education completed & 0.47 & 0.50 & 0.42 & 0.50 & 0.55 & 0.50 \\
Secondary education completed & 0.42 & 0.49 & 0.51 & 0.50 & 0.30 & 0.46 \\
Professional training course & 0.45 & 0.50 & 0.46 & 0.50 & 0.43 & 0.50 \\
Training on job & 0.27 & 0.45 & 0.28 & 0.45 & 0.25 & 0.44 \\
Self-taught & 0.28 & 0.45 & 0.26 & 0.44 & 0.32 & 0.47 \\
Wage-worker & 0.66 & 0.47 & 0.61 & 0.49 & 0.73 & 0.45 \\
Own-account & 0.28 & 0.45 & 0.31 & 0.46 & 0.25 & 0.44 \\
Micro-business (with 1-2 employees) & 0.06 & 0.23 & 0.08 & 0.27 & 0.02 & 0.15 \\
Observations & 200 & & 116 & & 84 & \\
\hline
\end{tabular}

Source: Author's elaboration based on the project survey data.

Notes: Summary statistics based on the full sample. * Association member figures are from the random sample consisting of 152 workers. ** The median wage is USD 9.6 overall, USD 9.9 for Nairobi, and USD 7.4 for Kisumu.

involves a lot of shoving and jostling among operators and riders and is characterized by negative public perception and unfavourable working conditions (Wright, 2018). Other reasons for low participation of women in the sector include harassment and intimidation as well as historical and cultural reasons that discourage women from entering such 'risky' jobs (Kamau \& Mitullah, forthcoming). This also mirrors the global trend where men dominate the sector (Wright, 2018). Nonetheless, women are increasingly taking up public transport jobs mostly as conductors.

The average daily income is about USD 11 and is around 25 percent higher in Nairobi compared with Kisumu. As expected, the median wage is lower than the mean (at USD 9.6 overall) due to the right skew of the distribution with a few heavy earners at the top pulling up the mean. For this reason, the median is often a more accurate measure of the general wage level. As for assets, only 28 percent own a house or land. In terms of education, 42 percent have attained secondary education or above (substantially higher in Nairobi), and 45 percent have attended a professional training course, whilst 27 percent have received training on the job. Most transport workers are wage-workers (66 percent), with the incidence being especially high in Kisumu at 73 percent. By contrast, the incidence of own-account workers is slightly higher in Nairobi (31 percent) than in Kisumu (25 percent). Finally, micro-businesses make up only 6 percent of the 
sampled workers. In the survey, the own-account operators were mostly motorcycle riders while the matatu operators had a higher representation among wageworkers. The relatively high rate of motorcycle ownership is attributed to low purchasing capital required for motorcycles ranging between KES 65,000 and 80,000 (Mwobobia, 2011). In contrast, owning a PSV requires high capital investment on top of which comes the cost of vehicle importation, registration, insurance, and general maintenance.

\section{Associational landscape}

Transport workers belong to different sub-sector-specific associations, for instance, matatu SACCOs or motorcycle associations, and even smaller informal welfare groups known as chamas (Kamau et al. 2018). There are also umbrella associations that represent the SACCOs, owners, and workers. Examples include the Matatu Owners Association $(\mathrm{MOA})^{1}$ in which own-account operators belong to Matatu Workers Association (MWA), Matatu Crew Workers Association (MaCREW), and the Boda-boda Association of Kenya (BAK). Together, these SACCOs and the associations account for the vast majority of members who belong to associations ( 80 percent), followed by the worker, trade, and businessspecific associations and unions (17 percent), and others like women and youth organizations and unions (3 percent). Interestingly, whilst the incidence of worker, trade, and business associations is higher in Kisumu, that of MOA, SACCOS, and chamas is substantially higher in Nairobi, thus indicating a difference in the type of and preference for associations across locations. There are also unions representing workers in the sector, and these include the Kenya Transport Workers' Union (TAWU), Matatu Workers Union (MWU), and the Public Transport Operators Union (PUTON). TAWU has representation in Nairobi and Kisumu, while MWU and PUTON are mainly in Nairobi. These unions are also allied to the International Transport Workers Federation (ITF).

As mentioned earlier, the survey data revealed that workers' membership in transport associations is relatively high at 67 percent, with 33 percent of workers not belonging to an association. Membership in transport associations in Kisumu is higher (78 percent) compared with 60 percent in Nairobi. The association enrolment-gap was associated with workers' reluctance to join SACCOs that could restrict their job mobility, failure by NTSA to involve operators in decisions relating to SACCOs formation and to set regulations that bind workers to remain for a specified period in SACCOs that facilitate their entry to jobs in the sector. As noted in the discussions, most workers perceive SACCOs merely as enablers for getting NTSA clearance and accessing jobs in the sector. Hence, as noted by a key informant, "PSV workers are not concerned about having social insurance and they comply with SACCO rules to get jobs".

Transport associations vary in membership size and structure and have formal and informal elements. The matatu associations, mainly the SACCOs, have a simple structure and are mainly geographical and route-based. The motorcyclist associations are largely multi-layered and hierarchy-based, with leadership 
structure being at the 'bases' or zonal levels, with further linkage to county and national levels. An example is the Boda-boda Association of Kenya (BAK) which is an umbrella association and has representation across the country including in Nairobi and Kisumu. In both Nairobi and Kisumu, bodaboda associations comprised 'base-groups' that had designated parking points. Each base has a leader and is represented at the zonal, county, and, in some cases, in the umbrella associations. For the motorcyclist, their associations are need-based, self-driven, and self-governed. Unlike matatu SACCOs, motorcycle grassroots associations create synergy among members. However, the PSV SACCOs are mostly formal and stable while motorcycle associations have greater flexibility but are shakier. Due to the high membership numbers, bodaboda associations are less stable and are occasionally marred by internal conflicts and splinter groups. They are also easily infiltrated by politicians who use them to get political mileage.

Table 5.2 presents selected summary statistics based on association members only. First, the table shows that association members have a slightly higher incidence of social insurance enrolment (49 percent) and health insurance coverage (52 percent) compared with the full sample of workers in Table 5.1 (47 percent and 50 percent, respectively). Again, both rates are significantly higher in Nairobi compared with Kisumu. In terms of association types, 80 percent of workers report being in SACCOs with close to 90 percent of workers in Nairobi. Regarding benefits, the majority of workers (46 percent) report loans as the main association benefit (especially in Nairobi) followed by work-related benefits (41 percent), voice and representation (9 percent), and finally, social cushioning (4 percent). Voice and representation are cited as more important among workers in

Table 5.2 Key worker characteristics, association members

\begin{tabular}{lllllll}
\hline & All & \multicolumn{3}{c}{ Nairobi } & \multicolumn{3}{c}{ Kisumu } \\
\cline { 2 - 7 } & Mean & SD & Mean & SD & Mean & SD \\
\hline Social insurance enrolment & 0.49 & 0.50 & 0.57 & 0.50 & 0.38 & 0.49 \\
Health insurance coverage & 0.52 & 0.50 & 0.65 & 0.48 & 0.35 & 0.48 \\
Association type & & & & & & \\
Sacco & 0.80 & 0.40 & 0.88 & 0.33 & 0.71 & 0.46 \\
Work-related association & 0.17 & 0.37 & 0.13 & 0.33 & 0.22 & 0.41 \\
Other association & 0.03 & 0.18 & 0.00 & 0.00 & 0.08 & 0.27 \\
& & & & & & \\
Benefit type & & & & & & \\
Work-related & 0.41 & 0.49 & 0.44 & 0.50 & 0.37 & 0.49 \\
Social cushioning & 0.04 & 0.20 & 0.03 & 0.16 & 0.06 & 0.24 \\
Voice and representation & 0.09 & 0.29 & 0.04 & 0.19 & 0.15 & 0.36 \\
Loans & 0.46 & 0.50 & 0.50 & 0.50 & 0.42 & 0.50 \\
Barriers (yes = 1) & 0.58 & 0.50 & 0.65 & 0.48 & 0.49 & 0.50 \\
Association fee (yes =1) & 0.83 & 0.38 & 0.74 & 0.44 & 0.94 & 0.24 \\
Observations & 145 & & 80 & & 65 & \\
\hline
\end{tabular}

Source: Author's elaboration based on the project survey data. 
Kisumu (15 percent) which could be related to the activities of traders generally being more regulated in Kisumu, and hence more issues on which associations may intervene.

Table 5.2 also shows that most transport associations ( 58 percent) have entry conditions, particularly, in Nairobi. In most cases, membership in SACCOs is vehicle-based, and except in a few cases like Kisumu Ahero Mowouk Transport Company in Kisumu, workers are not direct beneficiaries. Instead, they are in the SACCOs merely to get jobs, since this is a requirement by the NTSA. The vast majority of associations ( 83 percent) require payment of a one-off entry fee, ranging between USD 500 and 1,000. For the motorcycle associations, the entry fee is in the hundreds. In addition, vehicle owners are required to pay daily contributions for SACCO management. The owners and workers also contribute daily savings that range from about 1.5 to 2 USD for PSVs and about 0.2 to 2 USD for motorcycles. This money is used to cater for welfare issues and loans provision to members and in some SACCOs to cover social security. Some SACCOs like the Lakebelt and BAK require owners and also encourage workers to make investments savings through share capital contributions that are pooled to buy assets like vehicles or motorcycles. In most cases, investment in shares is voluntary.

\section{Highlights on selected transport associations}

\section{Matatu Welfare Association (MWA)}

MWA was formed in 1996 and formally registered in 2000. It grew out of protest against a proposal by the minister for transport in 1996 to introduce installation of 'technographic black boxes' in PSVs in order to capture road crash data in the event of an accident. The workers protested the high cost of the gadget estimated as USD 700 (KES 70,000) per piece. MWA is SACCO-based, and its vision is to protect workers in the matatu industry. Membership entails payment of a one-off fee of USD 100 (KES 10,000) and a monthly fee of USD 50 (KES $5,000)$ per SACCO. Since formation, MWA has played a key role in transforming the industry through lobbying, advocacy, and engagement with government, policy-makers, and key stakeholders as well as addressing the challenges facing the industry.

The association has, over time, engaged with the government on issues related to organization of the sector and compliance with regulations and has developed initiatives to support workers. In 2004, for instance, with the introduction of new matatu rules, MWA organized a benchmarking trip for its members to travel to Uganda to learn about maintaining workers discipline, vehicle branding, and speed governor installation. MWA was also involved in the development of the Integrated Public Transport Policy. Despite this, discussions revealed that MWA has not done much to address labour issues affecting workers. The association does not provide or support members' access to formal social insurance nor labour protection as the individual SACCOs are expected to facilitate this. 
Nonetheless, MWA supports members' welfare when need arises for instance in case of workers arrest or harassment by authorities on work-related issues (but not due to obstruction or overloading). The issue of supporting workers training and credit provision is also left to the SACCOs.

\section{Kisumu Abero Mowouk Transport Company, Kisumu}

Kisumu Ahero Mowouk Transport Company (KAMTCO) is a limited company started in 2010 and is registered with the Ministry of Co-operatives. The company has 11 directors (all men). To become an official, one must have a vehicle in the company. At the time of the interview, the company had 114 PSVs that belonged to members and an additional seven that belonged to the company. The company has four women investors while the rest are men. Membership benefits include protection against harassment by authorities and negotiation with authorities in case of an accident or other problem. As noted by an official, "it is the face of the company that is seen not that of the individual investors".

In terms of fleet management, vehicle owners are required to sign franchising contracts with the company. However, not all vehicles are managed by the company. At the time of the interview, only 30 vehicles had been franchised to the company for management, while the rest were managed by the owners. The company had employed 89 workers who included drivers, conductors, and stage managers. About half of them (41), mainly from the franchised vehicles, had formal work contracts. Once employed, the drivers and conductors are put on a three months' probation. If confirmed, they get formal contracts and have a regular monthly salary of USD 300 and 200 (KES 30,000 and 21,000), respectively. Each vehicle is assigned three off-board workers (Callers) and is charged KES 450 maintenance fee daily of which 300 is used to pay the three Callers and 150 is for office management. In addition, each vehicle contributes KES 200 daily (about USD 2), from which KES 100 is for SACCO management and KES 100 for vehicle owner savings.

The company makes regular contributions to NHIF to cover enrolled workers, even though few are enrolled. Out of the 89 workers, only 13 drivers and 6 conductors had enrolled in NHIF.

The vehicle owners are responsible for paying for workers social security, but most are reluctant due to high staff turnover. The workers thus pay for their NHIF and NSSF contributions, but their enrolment is low due to fear among most workers of being tied to employer-linked schemes. The drivers and conductors also get paid maternity and paternity leave. The company has a burial and benevolent fund which covers the 89 employees who contribute KES 20 daily. In addition, the company has a welfare and investment SACCO whose membership is open to non-vehicle owners, including the workers so long as they are based in Kisumu. Not all the 89 members are members of the welfare SACCO even though data on the number of workers who belonged to the SACCO were not obtained. In the SACCO, members contribute a minimum of KES 2,000 monthly for shares. In some cases, the money is used to purchase a SACCO 
vehicle from whose profits the members get annual dividends. In addition, the SACCO caters for members' welfare issues like medical expenses of drivers and conductors who belong to the SACCO, bereavement, and children's education support through school fee loans. This means that workers who are on contract and are members of the SACCO can benefit both from the company and the SACCO.

Discussions with the company officials revealed that despite having a savings and investment SACCO, the workers and members have a poor saving culture. To address the challenge, the company organizes training for the members. For instance, it engaged the British-American Insurance Company (BRITAM) to educate members on importance of joining social insurance schemes, and the National Industrial Training Institute (NITA) to train members on financial literacy among other aspects. In addition, the company organizes exchange visits for workers so as to learn from successful SACCOs in Central Kenya like the $2 \mathrm{NK} .{ }^{2}$ Whereas the company is considered to be a success, it faces challenges like interference by politicians especially during political campaigns, worker harassment by authorities, and high staff turn-over. The refusal by some owners to franchise their vehicles to the company also weakens the company's management and control of workers.

\section{Kaloleni Shauri Moyo Boda-boda SACCO}

The SACCO was formed in September 2018 with about 120 members from seven bases. The number had grown to about 56 bases with over 1,000 members at the time of the interview. The idea to form the SACCO arose after some members visited Rwanda for a benchmarking trip sponsored by the County Government. Upon returning to Kenya, they formed the SACCO to implement the good practices that they had learnt, for instance, on riders' discipline, traffic regulations on passenger carrying capacity, having driving licenses, and keeping the work areas clean.

The SACCO has an open membership, and at the time of the interview, it also admitted members who did not own motorcycles. The SACCO was organized around zone groups (community-based) and below them were the 'bases' with the leadership structure having representation from different zones and bases. Each base is self-governing with own rules and regulations, that include determining the members' registration fee, although the minimum is KES 200. Some bases require members to pay up to KES 2,000 to join. Membership requirements include being over 18 years old and being registered with a base. At the time of the interview, the SACCO had about 40 women members, some of whom were not riders. Some owned motorcycles and had employed riders and some had businesses near the bases.

Registration is also required at the SACCO level. Here, members pay KES 200 registration fee, KES 100 daily to the SACCO, and KES 50 daily contribution. Once collected, the money is banked by the SACCO under its savings portfolio. Each group (base) contributes KES 750 per week of which KES 50 is 
for supporting office operations, KES 200 is put in members' savings, and KES 500 is for merry-go-round contributions that are used to give members loans. The officials estimated that, every month, the SACCO advances loans of up to KES 72,500 to members. From the onset, the SACCO aimed at empowering members to own motorcycles so as to stop being employed (kodesha). Within one year of formation, 67 members had received loans to purchase motorcycles. Additional financial support is sought from banks and cooperatives. For instance, the SACCO had acquired a loan from Equity Bank to purchase 10 motorcycles and from UNAITAS Savings and Credit Cooperative Society Limited to purchase 20 motorcycles.

The SACCO provides other benefits to members. For instance, supporting training on financial management, driving, and road safety as well as getting third-party motorcycle insurance through a local insurance company at a cost of KES 5,800, but the riders were not covered. Instead, they contributed KES 80 daily to cover for eventualities like accidents. At the time of interview, the SACCO had a welfare fund that catered for bereavement in case of death of a member or a family member, with each member contributing an additional KES 200 if a member was bereaved. In addition, each base was required to give matching contributions of KES 200. The funds covered funeral expenses like coffin, transport, and mortuary fees. The SACCO also had a school fees kitty which supported children of members who joined secondary schools.

A key challenge facing the SACCO as discussed with the officials is internal conflicts that sometimes lead to the formation of splinter groups. There is also interference by politicians, and this affects the SACCO management. As noted, officials and members who have close ties with political leaders approach them to get support to benefit themselves, and not necessarily, the workers. This undermines the SACCO leadership and causes conflict among the members.

\section{The power resources framework}

This chapter, like the rest of the book, is guided by the power resources approach (PRA) analytical framework which is based on the premise that, if organized, labour can successfully defend its interests by collectively mobilizing different power resources. Put differently, and as implied by Lund (2009), informal workers' organizations can be a gateway to the realization of informal workers' rights. The workers thus need not only to have rights but they also need to be aware about their rights and be able to claim, protect, and maintain them. These 'rights stages' can be achieved through use of different forms of power that include structural, associational, institutional, and societal power. In the transport sector, the workers' exercise of these powers varies by sub-sector. This chapter explores the different forms of PRA that are used by transport workers and examines whether belonging to associations enhances workers' ability to claim and defend their interests. For instance, the fact that matatu workers are mostly employed and belong to SACCOs, while the bodaboda workers are mainly ownaccount operators, means that different PRAs are used to protect their interests. 


\section{Anne W. Kamau}

\section{Structural power}

As a form of labour power, structural power includes the marketplace, workplace, and regime-disruptive powers. The position of informal transport workers in the work- and marketplaces is weak mainly because the sector is under-valued, and workers are still to a large extent perceived as rogue workers. The large pool of available workers also means that workers are easily replaceable. However, the workplace bargaining power is stronger due to the large number of workers that increases their ability to disrupt operations. From the onset, workers enter into a sector that is not fully appreciated or recognized, and one that does not have systems that enable workers to easily access or claim their labour rights. The sector, being informal and without supportive structures, weakens the workers bargaining position. Most transport workers, especially the matatu workers and some bodaboda operators, are employed, and their work compensation and benefits are pegged on informal contracts. Except in a few cases, mainly for bodaboda operators who own the motorcycles, transport workers do not own the vehicles, and even though they control the income from the vehicles, their job security is not guaranteed. Equally, the SACCOs they belong to largely serve the interests of vehicle owners, even though, in a few cases, some SACCOs facilitate workers' access to social protection. The lack of work- and marketplace power means that workers' negotiation space is limited even for demanding for their right to social security. Thus, other than pushing for better working environment, most workers, especially in the matatu sub-sector, prefer to change jobs or employers, and this contributes to some workers' unwillingness to have employer-linked social security provision. In the discussions in Kisumu, some matatu workers indicated that they avoided enrolling in schemes initiated by their employers due to fear that this could curtail their job mobility. Hence, as shown later in Table 5.3, there is not much difference between the association and nonassociation members regarding social insurance enrolment and health insurance coverage among the sector workers.

Transport workers in both the matatu and motorcycle sub-sectors have strong disruptive power which they exercise collectively as workers at different levels to disrupt the economy and demand for their rights. Though not formally documented, the informal transport sector contributes greatly to Kenya's economy and is a key employer. Matatu and bodaboda operators are many and have strong power which they use from time to time to make demands on issues that affect them. For instance, they use blockages, strikes, threats, and traffic disruptions to demand for action from government and authorities. There have been instances where matatu or bodaboda workers collectively, but separately, use regimedisruptive power to resist government directives, demand for leniency, or push the government to retract decisions that threaten their jobs or sector operations. Recent examples include paralyzing of transport operations in Nairobi due to poor state of roads, introduction of the bus-rapid transit (BRT), intended removal of matatus from the central business district, increased fuel prices, or police harassment and crackdowns. The bodaboda operators also block streets to 
Table 5.3 Differences in key workers characteristics by association member status

\begin{tabular}{lccrr}
\hline & Member & Not Member & Difference & t-Value \\
\hline Social insurance enrolment & 0.49 & 0.44 & 0.05 & 0.67 \\
Health insurance coverage & 0.52 & 0.45 & 0.06 & 0.79 \\
Nairobi & 0.55 & 0.65 & -0.10 & -1.31 \\
Kisumu & 0.45 & 0.35 & 0.10 & 1.31 \\
Gender (male = 1) & 0.96 & 1.00 & -0.04 & -1.53 \\
Married & 0.88 & 0.82 & 0.06 & 1.19 \\
Local & 0.30 & 0.27 & 0.02 & 0.33 \\
Age & 36.28 & 35.85 & 0.42 & 0.30 \\
Mean daily earnings (current & 10.88 & 11.16 & -0.28 & -0.25 \\
$\quad$ USD) & & & & \\
Assets (house and/or land) & 0.21 & 0.44 & -0.22 & $-3.21^{* * *}$ \\
Primary incomplete & 0.11 & 0.09 & 0.02 & 0.40 \\
Primary complete & 0.47 & 0.49 & -0.02 & -0.28 \\
Secondary or above & 0.42 & 0.42 & 0.00 & 0.03 \\
Training course & 0.43 & 0.49 & 0.06 & -0.80 \\
Training on job & 0.27 & 0.27 & 0.00 & 0.05 \\
Self-taught & 0.30 & 0.24 & -0.07 & -0.94 \\
Wage-worker & 0.63 & 0.75 & 0.12 & 1.57 \\
Own-account & 0.30 & 0.24 & -0.07 & -0.94 \\
Micro-business & 0.07 & 0.02 & -0.05 & -1.41 \\
Observations & 200 & & & \\
\hline Sorce Aun & & & & \\
\hline
\end{tabular}

Source: Author's elaboration based on the project survey data.

Notes: $<0.01^{* * *},<0.05^{* *},<0.1^{*}$.

demand for release of arrested peers and to be allowed access to the CBD. Compared to matatu workers, the motorcycle workers have less recognition but have higher disruptive power. They are perceived more negatively by the public compared to the matatu workers. Hence, their disruptive power is targeted not only to the authorities but also to the public, for instance, when accidents involving one of their own occurs. Incidences of burning of vehicles involved in accidents with bodabodas have been common across the country forcing the government to issue stern warning to the operators.

\section{Associational power}

The informal sector is known to have strong associational power which has, over the years, been leveraged by various agencies to economically empower and organize workers in the sector. In Kenya, the matatu sector workers belong to transport SACCOs that are regulated by government and to informal groups commonly known as chamas. Bodaboda operators also belong to self-regulating associations and informal groups. The SACCOs, associations, and chamas provide varying support to advance owners' and workers' interests, and this depends on the reasons for formation. In the case of matatu SACCOs, workers join them to be registered with NTSA and to access jobs. In some cases, the SACCOs, the bodaboda associations, and even some chamas facilitate workers' access to 


\section{Anne W. Kamau}

saving facilities and access to loans. Some also support workers' welfare needs. All-in-all, the intentions and reasons for joining the associations vary. Joining the SACCOs is mandatory for matatu workers, but this is not a requirement for bodaboda operators. Also, unlike the bodaboda associations that are formed voluntarily by sub-sector operators, matatu SACCOs are formed mainly by vehicle owners, and the workers fit in and are not involved in governance of the SACCOs. Hence matatu workers have little allegiance to their SACCOs and doubt the SACCOs' willingness to protect workers' interests. This is unlike the bodaboda operators who have greater attachment to their associations but, as noted earlier, are shakier due to internal and external interference.

\section{Institutional power}

Institutional power has to do with laws, regulations, procedures, and practices that regulate relationships between workers, employers, and authorities. In Kenya, institutional power exercised over the matatu sector is strong and is often used to regulate operators. There are formal institutions that regulate the sector, like the NTSA and the NPS, but these do not necessarily translate into power for the workers. This chapter maps the larger institutional framework and further reflects on the position of the workers within this framework. Results show that, to work in the sector, one must belong to a registered transport SACCO. Therefore, by default, joining of SACCOs is institutionally pre-determined. The NTSA requires SACCOs and employers to hire workers on formal contracts and provide them with social security. In practice, though, this does not happen, and as noted earlier, most matatu workers are hired by vehicles owners and not the SACCOs, mainly on individually negotiated verbal work contracts. A few SACCOs like KMO and Olokise SACCOs in Nairobi and Kihomi SACCO in Kisumu provide work contracts and social security for workers. However, most SACCOs do not engage workers formally partly due to reluctance by vehicle owners to fully release the vehicles to SACCOs to manage them. Thus, whereas there are legal provisions for employment of workers, in practice, these provisions are not enforced. Hence, the institutional power is exercised at the level of control by the government over the sector, and by SACCOs, over the workers while serving the interests of vehicle owners.

The situation is however different for motorcycle operators. First, it is not mandatory for them to belong to SACCOs. The government has also not provided regulations for hiring bodaboda workers, even though a higher number are own-account operators. Nonetheless, most of them belong to work-related associations that are registered under the Associations Act. Once registered, the associations can enrol workers and also decide on the kind of support to provide to them.

The issuance of PSV licenses by NTSA to SACCOs and badges to workers is a form of control and regulation of the sector. Only licensed vehicles and workers can work in the sector, even though there are some workers who find their way into the sector even when not licensed like the reliever drivers, known as squad 
drivers, who work on mutually agreed terms with the regular drivers towards the end of trips. The licensing requirement nonetheless has protective benefits for matatu workers as only authorized persons can work in the sector. The benefits are even greater for the drivers given that only those having Class A driving license are permitted to drive PSVs. This raises their competitive value (a form of marketplace bargaining power) and makes them more difficult to replace, thus increasing their marketplace bargaining power discussed above. Discussions with the workers revealed that Class A drivers are highly sought after. There is nonetheless a negative effect associated with high staff turn-over due to the common practice of poaching drivers, especially by new vehicle owners. This further weakens the SACCOs ability to contain workers and to negotiate their access to social security. An official of Kihomi SACCO noted that, annually, about 12 out of 52 drivers and 20 out of 30 conductors leave their jobs despite having formal work contracts and regular salary. In general, SACCOs cannot restrict workers' job mobility unless they have unpaid SACCO loans or pending criminal cases that hold SACCOs accountable.

Figure 5.1 summarizes the authors' interpretation of the relationships between the government, SACCOs, vehicle owners, and workers in the matatu sub-sector. The relationships, though co-dependent especially between SACCOs, owners, and workers, are also based on a power hierarchy where the government wields overall power, whereas the SACCOs and owners have power over workers. However, even in this arrangement, the workers hold some financial control over the owners since they collect fares and remit daily to the owners as per agreed target.

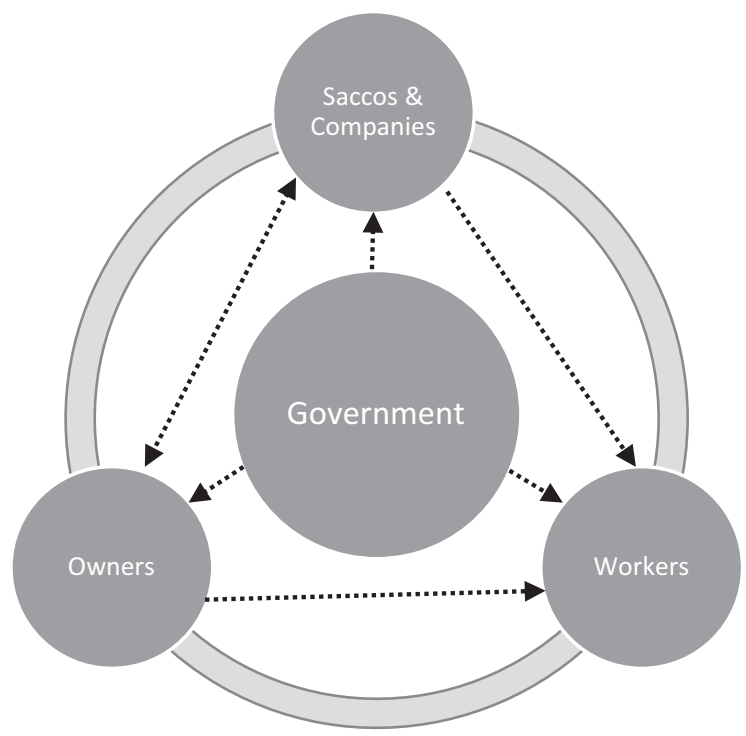

Figure 5.1 Power relations in the matatu sub-sector. 
The scenario within the matatu sector is one of mutual dependency. SACCOs depend on owners to give them vehicles, so as to be registered with NTSA. The SACCOs support the owners in registration and licensing of vehicles and the workers by NTSA. Vehicle owners are the employers, even though, ideally, it is the SACCOs that should employ workers. Few vehicle owners agree to franchise their vehicles to SACCOs to manage them, and this reduces the SACCOs authority over workers. In practice, the SACCOs largely favour the interest of vehicle owners and pay little attention to workers' issues. Hence, there are tensions between SACCOs and workers. Associations like MOA and KMO mainly protect vehicle owners' interests. Others like MWA, MaCREW, and Kisumu Boda-boda Association engage with the government and authorities to pursue the SACCOs, associations, and workers' interests and long-term policy changes in the sector. For example, MWA successfully lobbied for reduction of insurance premiums for 14-seater matatus, and this benefited the entire sector. Also, in 2018, 31 SACCOs petitioned the government to suspend the removal of 14-seater PSVs from operating in Kenya (ROK, 2018). There are also transport unions like TAWU, MWU, and PUTON ${ }^{3}$ that cater for workers' interests. However, none of the workers in the survey belonged to a union, but other studies in Kenya have covered them (Wright, 2018; Spooner \& Manga, 2019). The low participation in union activities is linked to limited time among workers to participate in union activities due to nature of their work, or their SACCOs and employers dissaproval of their joining unions. Some of the unions like TAWU were established to cater for formally employed workers, and it has only very recently begun to recruit informal workers, whereas the independent union MWU was established specifically to cater for informal workers.

\section{Societal power}

Societal power includes coalitions that involve forming alliances with actors and other social groups as well as the discursive power which is about influencing the public. Transport workers have higher coalition power through their associations. Some SACCOs partner with state and non-state organizations like NTSA, NITA, KUSCCO, the police, and insurance companies to support and benefit workers. Examples include KAMTCO which formed coalitions with the BRITAM and NITA to train workers. The Kisumu Boda-boda association also partnered with a local insurance company to facilitate members' access to training and insurance cover. Others like KMO in Nairobi supported workers to access health insurance, while Kihomi organized workers exchange visits with successful transport SACCOs in other regions and also facilitated workers access to savings and credit through organizations like KUSCCO.

Regarding discursive power, transport workers and their associations have not achieved much in changing public perception and opinion towards the sector. The only time that the public supports transport workers is when they are directly affected, for instance, when PSVs are barred from accessing the CBD. Often, the public is on the receiving end when transport workers conflict with 
authorities, for instance, when fuel costs are increased leading to increase in fares. The perception is even worse with regard to motorcycle operators due to poor accident ratings, and their tendency to mob and harass motorists involved in accidents with one of their own. Thus, even when workers are disadvantaged or denied their right to social protection, public opinion is unlikely to tilt in favour of workers.

\section{Discussion}

\section{Comparison between members and non-members}

Table 5.3 shows that there are no significant differences along a variety of dimensions between association members and non-members, except for asset ownership which is higher among the non-members. Non-members also have higher earnings and are more likely to be in Nairobi (although the differences are not statistically significant). Members consist of a relatively higher proportion of own-account operators and a lower proportion of wage-workers compared to non-members. This is likely due to the more insecure nature of the former work type, in turn, increasing the need for associational belonging.

\section{Access to formal social insurance}

Despite the government requirement that transport workers should have social insurance, around 50 percent of workers remain uncovered as seen in Tables 5.1 and 5.2 . Tables 5.3 and 5.4 reveal that, although association members in general are more likely to have coverage, the difference is not statistically significant, with the exception of SACCO members, as discussed further on. This could be due to the fact that, on the whole, the vehicle owners expect the workers to pay for their own coverage due to the notion that they control the daily incomes. In the matatu sector, fare payment is largely cash and is often handled by workers. Alternative cashless payment options are not common, and this makes the owners suspicious that the workers do not remit the entire daily earnings. To deal with this fear, workers are put on a set daily target (Spooner \& Manga, 2019) and are left to cater for their social security needs. Unlike the formal sector, where part of the contributions, for instance, to pension coverage, is paid by the employer, this is not the case in the informal sector - including even those who have formal work contracts from SACCOs. As noted earlier, workers who are enrolled in social security programmes through the SACCOs still pay for their own coverage. Table 5.4 also shows that male and self-taught workers are less likely to have formal social insurance; yet, the sector is male-dominated.

Factors that contribute to workers' low social insurance include employers' refusal to pay for workers' coverage, high worker turn-over, workers' unwillingness to enrol in employer-linked schemes, low awareness, and high cost of premiums. A few SACCOs comply with NTSA requirements to enrol workers 
Table 5.4 Differences in key workers characteristics by social insurance enrolment

\begin{tabular}{lccrc}
\hline & $\begin{array}{l}\text { Social } \\
\text { Insurance }\end{array}$ & $\begin{array}{l}\text { No Social } \\
\text { Insurance }\end{array}$ & Difference & t-Value \\
\hline Association member & 0.75 & 0.70 & 0.04 & 0.67 \\
Sacco/vicoba/chama & 0.65 & 0.51 & 0.14 & $1.99^{* *}$ \\
Work-related association & 0.08 & 0.15 & -0.07 & -1.48 \\
Women/youth/religious & 0.01 & 0.04 & -0.03 & -1.25 \\
Work-related & 0.29 & 0.30 & 0.00 & 0.01 \\
Loans & 0.36 & 0.31 & 0.04 & 0.65 \\
Voice and representation & 0.05 & 0.08 & -0.02 & -0.67 \\
Social cushioning & 0.04 & 0.02 & 0.02 & 0.95 \\
Kisumu & 0.63 & 0.53 & 0.10 & 1.41 \\
Nairobi & 0.37 & 0.47 & -0.10 & -1.41 \\
Gender (male = 1) & 0.95 & 0.99 & -0.04 & $-1.79{ }^{*}$ \\
Married & 0.89 & 0.84 & 0.06 & 1.17 \\
Local & 0.27 & 0.30 & -0.03 & -0.48 \\
Age & 36.99 & 35.41 & 1.58 & 1.26 \\
Mean daily earnings (current & 11.02 & 10.90 & 0.12 & 0.12 \\
$\quad$ USD) & & & & \\
Assets (house and/or land) & 0.22 & 0.32 & -0.10 & -1.63 \\
Primary incomplete & 0.08 & 0.12 & -0.04 & -0.91 \\
Primary complete & 0.46 & 0.49 & -0.02 & -0.32 \\
Secondary or above & 0.45 & 0.39 & 0.06 & 0.89 \\
Training course & 0.47 & 0.42 & 0.05 & 0.77 \\
Training on job & 0.31 & 0.24 & 0.07 & 1.07 \\
Self-taught & 0.22 & 0.34 & -0.12 & $-1.91^{*}$ \\
Wage-worker & 0.64 & 0.68 & -0.03 & -0.51 \\
Own-account & 0.29 & 0.28 & 0.02 & 0.29 \\
Micro-business & 0.06 & 0.05 & 0.02 & 0.48 \\
Observations & 200 & & & \\
\hline Sorcesthors & & & & \\
\hline
\end{tabular}

Source: Author's elaboration based on the project survey data.

Notes: $<0.01^{* * *},<0.05^{* *},<0.1^{*}$.

in social insurance while others encourage the workers to enrol voluntarily. This could explain the finding that SACCO members are more likely to be enrolled in social insurance (Table 5.4). However, the reluctance among vehicle owners to allow SACCOs to fully manage their vehicles including employing workers weakens the SACCOs ability to ensure workers' provision of social insurance. Hence, the workers' access to social insurance is not dependent on association membership but on whether the SACCOs they belong to have full mandate to manage worker issues.

The co-dependence between SACCOs and vehicle owners and lack of structures to ensure compliance with government directives compromises workers' access to social protection. The lack of full control of incomes from the vehicles by the owners makes them reluctant to use their earnings, which they consider to be low, to provide for workers' social insurance. The owners' perspective is that workers control the earnings from the vehicles and that they can afford to pay for their own social security coverage. Hence, many employers do not consider provision of workers' social protection as their responsibility. The workers on their 
part argue that their net incomes are low and that they have competing personal and family demands and therefore not in a position to pay for social security. In Kisumu, the vehicle owners observed that:

The workers are our bosses; they employ us because they control the amount that the vehicles earn. They determine how much money the vehicle owners get at the end of the day, after they have paid themselves. They have a lot of money and they can afford to pay for their social protection coverage. The vehicle owners have little control of the vehicle operations and there are no systems to protect us. The money that we get is mainly used to repay the vehicle loans.

(FGD, Kisumu)

\section{Conclusion}

The informal public transport sector is one of the largest in Kenya. It includes matatu and motorcycle sub-sectors. The sector is highly regulated by government. For instance, it is mandatory for matatu workers to belong to SACCOs. This is, however, not mandatory for motorcycle operators, even though most of them belong to sector-based associations. Transport SACCOs and associations benefit workers by engaging with and lobbying authorities on behalf of workers on operations-related issues. However, they hardly address workers' social protection issues like social insurance provision, even when this is required by NTSA in the case of matatus. The sector is beset with many challenges that affect workers' social protection provision, like lack of formal work contracts. Consequently, most workers depend on informal systems and networks when faced with shocks. The reluctance by vehicle owners to franchise vehicles to SACCOs for management, lack of enforcement to compel employers to provide workers with formal contracts and social security, and workers' fear of joining labour unions contribute to the low social security coverage among workers. This also denies workers their right to work in favourable and decent work environments.

Whereas transport SACCOs and associations exist, they mainly protect the interests of vehicle owners and not of workers. Hence, the workers fear to voice their concerns or to approach their associations whenever they have workrelated challenges, except when they require the SACCOs and associations to engage with authorities on their behalf. Some SACCOs support workers by providing training, access to credit, or catering for welfare needs. There is, however, little variation in social protection coverage between workers who belong to associations and those who do not. This chapter thus concludes that having government social protection policies and regulations in place is important. However, this does not guarantee workers access to social protection. The role of transport SACCOs and associations needs to be re-examined with a view to compelling them to focus on workers' issues including their right to social insurance. 


\section{Notes}

1 Workers in Kisumu indicated that MOA was inactive there and that not all owners are members.

2 https://www.2nksacco.co.ke/.

3 PUTON is an independent democratic registered trade union in Kenya which is affiliated to the International Transport Workers Federation. It draws membership and represents workers in transport-oriented occupations.

\section{References}

Behrens, R., McCormick, D., Orero, R. \& Ommeh, M. (2017) Improving paratransit service: Lessons from inter-city matatu cooperatives in Kenya. Transport Policy. 53, 79-88. Available from: doi:10.1016/j.tranpol.2016.09.003.

Devereux, S. \& Sabates-Wheeler, R. (2004) Transformative social protection. IDS Working Paper 232. Brighton, Institute of Development Studies.

ILO (2020) Case studies: Developing a business case for labour law compliance. International Labour Organization. Geneva, International Labour Office. Available from: https://www.ilo.org/wcmsp5/groups/public/---africa/---ro-abidjan/---ilo-dar_es_ salaam/documents/genericdocument/wcms_500927.pdf.

Kamau, A. \& Mitullah, W.V. (forthcoming) Women's value creation in informal public transport enterprises in Kenya. In: Yousafzai, S., Henry, C., Boddington, M., Sheikh, S. \& Fayolle, A. (eds.) Research handbook of women's entrepreneurship and value creation. Cheltenham, UK, Edward Elgar Publishing Limited.

Kamau, A., Kamau, P., Muia, D., Baiya, H. \& and Ndung'u, J. (2018) Bridging entrepreneurial gender gap through social protection among women small scale traders in Kenya. In: Yousafzai, S., Fayolle, A., Lindgreen, A., Henry, C., Saeed, S. \& Sheikh, S. (eds.) Women's entrepreneurship and the myth of 'underperformance'. Cheltenham, UK: Edward Elgar Publishing Limited.

Kamau, A., Michuki, G., Kamau, P. \& Mwangi, S. (2019) Overcoming challenges in extending pension coverage to informal sector workers in Kenya. Research Paper, Retirement Benefits Authority (RBA).

Lund, F. (2009) Social protection and the informal economy: Linkages and good practices for poverty reduction and empowerment. In: Promoting pro-poor growth: Social protection. Geneva, Organisation for Economic Cooperation and Development (OECD), pp. 69-88.

McClean, E.J., Burris, E.R. \& Detert, J.R. (2013) When does voice lead to exit? It depends on leadership. The Academy of Management Journal. 56 (2), 525-548. Available from: http://www.jstor.com/stable/23412601.

Mutongi, K. (2017) Matatu: A history of popular transportation in Nairobi. Chicago, IL, University of Chicago Press.

Mwanza, E. (10 February 2021) Nairobi residents rank best matatu Saccos. Kenyans.co.ke. Available from: https://www.kenyans.co.ke/news/62090-nairobi-residents-rank-bestmatatu-saccos.

Mwobobia, B. (2011) Critical success factors in the motorcycle boda-boda business in Nairobi, Kenya. MA thesis. University of Nairobi.

NTSA (2014) National transport and safety authority (operation of public service vehicles) regulations, 2014: Subsidiary legislation. National Transport and Safety Authority. Nairobi, Government Printer. 
Omulo, C. (12 February 2020) Revealed: 420 matatu saccos operating in Nairobi illegally. Daily Nation. Available from: https://www.nation.co.ke/kenya/counties/ nairobi/revealed-420-matatu-saccos-operating-in-nairobi-illegally--249852.

Opondo, V. \& Kiprop, G. (2018) Boda motorcycle transport and security challenges in Kenya. NCRC Research Report No. 14. National Crime Research Centre. Nairobi, The Jomo Kenyatta Foundation.

ROK (2012a) Laws of Kenya: Transport licensing act chapter 404. Revised Edition 2012 [1979]. Republic of Kenya, National Council for Law Reporting with the Authority of the Attorney-General.

ROK (2012b) Laws of Kenya: Co-operative societies act chapter 490. Revised Edition 2012 [2005]. Republic of Kenya, National Council for Law Reporting with the Authority of the Attorney-General.

ROK (2018) In the high court of Kenya at Nairobi constitutional \& buman rights division petition no. 440 of 2018. Republic of Kenya. Available from: http://kenyalaw.org/ caselaw/cases/view/198871/.

ROK (2020) The traffic (driving schools, driving instructors and driving licences) rules, 2020. Legal Notice No. 28 The Traffic Act (Cap. 403). Special Issue Kenya Gazette Supplement No. 19 (Legislative Supplement No. 12), 10 March 2020. Available from: http://kenyalaw.org/kl/fileadmin/pdfdownloads/LegalNotices/2020/LN28_ 2020.pdf.

Spooner, D. \& Manga, E. (2019) Nairobi bus rapid transit: Labour impact assessment research report. Manchester, Global Labour Institute. Available from: https://www. researchgate.net/publication/330398422_Nairobi_Bus_Rapid_Transit_Labour_ Impact_Assessment_Research_Report.

Spooner, D. \& Whelligan, J. (2017) The Power of Informal Transport Workers: An ITF Education Booklet. Manchester, Global Labour Institute. Available from: https://www. itfglobal.org/media/1691170/informal-transport-workers.pdf.

World Bank (2019) Implementation completion and results report: Report no: ICR00004798. Available from: http://documentsl.worldbank.org/curated/en/ 702181563299068935/pdf/Kenya-National-Urban-Transport-Improvement-Project.pdf.

Wright, T. (2018) The impact of the future of work for women in public transport. International Transport Workers' Federation (ITF), Friedrich Ebert Stiftung \& Women Transporting the world. 